\title{
ARTíCULO \\ Spatial distribution, density and population structure of the Cortes geoduck, Panopea globosa in the Central Gulf of California
}

Distribución espacial, densidad y estructura poblacional de la almeja de sifón Panopea globosa en la parte central del Golfo de California

\section{E. Alberto Aragón-Noriega ${ }^{1}$, Luis E. Calderon-Aguilera ${ }^{2}$, Edgar Alcántara-Razo ${ }^{1}$ and Jaime E. Mendivil-Mendoza ${ }^{1}$}

\begin{abstract}
${ }^{1}$ Centro de Investigaciones Biológicas del Noroeste, Unidad Sonora, Km 2.35 Camino al Tular, Estero Bacochibampo, Guaymas, Sonora 85454, México. aaragon04@ cibnor.mx

${ }^{2}$ Centro de Investigación Científica y de Educación Superior de Ensenada. Carretera Ensenada-Tijuana 3918, Ensenada, Baja California 22860, México

Resumen.- La almeja de sifón Panopea globosa es una especie de importancia comercial por su alta demanda en el mercado de Asia. El propósito de este estudio fue analizar el efecto de la concentración de clorofila, temperatura superficial del mar, turbidez y ciclo de mareas en la estimación de la densidad, distribución espacial, y estructura poblacional de la almeja P. globosa en la región central del Golfo de California usando datos de satélite y observaciones de campo. Los organismos fueron recolectados mediante buceo semi-autónomo, entre noviembre 2009 y enero 2011. Se recolectaron un total de 10.114 almejas con un peso promedio de $997 \pm 212 \mathrm{~g}(80 \% \geq 800 \mathrm{~g})$, y una longitud promedio de $132 \pm 12,5 \mathrm{~mm}$ ( $80 \%$ de los organismos recolectados estuvieron por arriba de $130 \mathrm{~mm}$, que es la talla mínima legal de pesca). La densidad de P. globosa del área de estudio presentó diferencias significativas entre las 3 agregaciones identificadas con alta densidad, pero la densidad no estuvo correlacionada con ninguno de los factores ambientales considerados.
\end{abstract}

Palabras clave: Pesquería, manejo, Golfo de California, almeja de sifón

Abstract.- The geoduck clam Panopea globosa is a commercially important species because of its high market demand, particularly in Asia. The aim of this study was to analyze the effect of chlorophyll concentration, sea surface temperature, turbidity, and tidal cycle on density estimation, spatial distribution, and population structure of P. globosa in the central Gulf of California using remote sensing and field survey data. Specimen collections were conducted through semiautonomous diving from November 2009 to January 2011. A total of 10,114 clams were obtained with an average weight of $997 \pm 212 \mathrm{~g}(80 \% \geq 800 \mathrm{~g})$, and an average length of $132 \pm 12.5 \mathrm{~mm}$ ( $80 \%$ of all collected clams exceeded $130 \mathrm{~mm}$, the minimum legal fishing size). P. globosa distribution displayed significant differences among the 3 patches of high density in the study area, but density was poorly correlated with the environmental factors.

Key words: Fishery, management, Gulf of California, geoduck

\section{INTRODUCTION}

The Cortes geoduck Panopea globosa (Dall, 1898) is one of two geoduck clam species in Mexican waters. Panopea generosa (Gould, 1850) ranges from southern Alaska to the western coast of the Baja California Peninsula (Goodwin \& Pease 1991). A prospective fishery for both species was initiated in Mexico in the early 2000s, and the catch skyrocketed to 1325 ton in 2011 (CONAPESCA 2012). Presumably, the increased catch resulted from Asian market demand and other suppliers facing over-exploited resources. The current reported catch was over 2100 ton annually, comprising both $P$. generosa and $P$. globosa. However, $P$. globosa contributed to more than $85 \%$ of the total catch (Aragón-Noriega et al. 2012).
Panopea globosa was first described by Keen (1971) based on empty shells found near San Felipe and Isla San Marcos in the upper Gulf of California. Hendrickx et al. (2005) included the species in a taxonomic checklist of macro-invertebrates, but no data was provided on species distribution. Former records restricted $P$. globosa distribution in the Gulf of California. However, Suárez-Moo et al. (2013) extended its range as far as Bahía Magdalena $\left(24.6^{\circ} \mathrm{N}\right)$ on the western coast of the Baja California Peninsula, clearly outside the Gulf (Fig. 1). Interestingly, P. generosa and P. globosa have exhibited an overlapping distribution at Bahía Magdalena (Leyva-Valencia et al. 2012); however, the continued distribution of P. globosa 


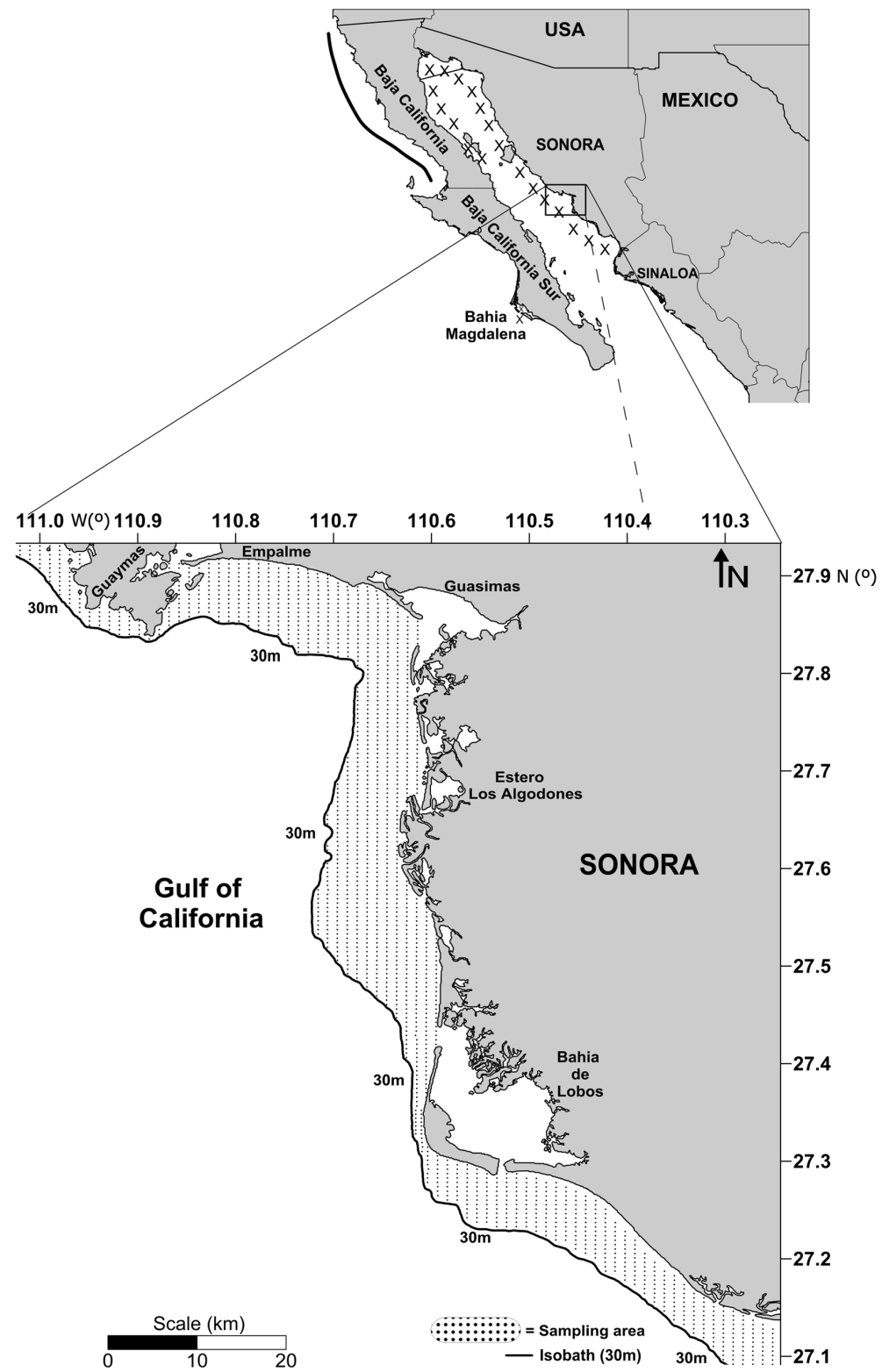

Figure 1. Study area showing the sampling grid. The distribution of Panopea globosa (crosses) and P. generosa (line) based on verified records in Mexican waters is show $\mathbf{n}$ / Área de estudio mostrando la malla de muestreo. Se indica la distribución de Panopea globosa (cruces) y P. generosa (línea) verificada con registros de pesca en aguas mexicanas

along the western coast of the Baja California peninsula northward from Bahía Magdalena still remains unknown.

The current knowledge available for P. globosa in the central Gulf of California (CGC) has been limited to reproductive traits (Aragón-Noriega et al. 2007, Arámbula-Pujol et al. 2008) growth analyses (Cortez-Lucero et al. 2011, Cruz-Vásquez et al. 2012), and distribution and abundance (Cortez-Lucero et al. 2014). These 5 studies used data from the CGC where the geoduck fishery is still in its initial stages (Aragón-Noriega et al. 2012). The management plan (DOF 2012) ${ }^{1}$ requires bed identification, i.e., geographic localities, and density estimation

${ }^{1}$ DOF. 2012. Agreement by which the management plan for geoduck (Panopea globosa) fishery in the coasts of Sonora, México is made known. Diario Oficial de la Federación. Ciudad de México, México, November 2012. <http://www.dof.gob.mx> 
at each site to issue fishing permits. The Mexican fishery regulation requires that any entity requesting a fishing permit must provide density estimates. Therefore, the first step is to request a polygon where a specific natural resource is known to occur, as in the case of the geoduck clam. Once the authority has granted permission to explore the area, a third party, contracted by the entity requesting the fishing-permit, conducts density estimation surveys. The authority (Comisión Nacional de Acuacultura y Pesca - CONAPESCA $)^{2}$ subsequently grants the adequate fishing quota; for example, the quota might be $0.5 \%$ of the estimated virgin biomass if it is a preliminary (fomento) permit or $1.0 \%$ if it is a commercial permit. Therefore, the knowledge of density and spatial distribution in P. globosa is integral for management purposes. In addition, assessment of environmental effects on the species spatial distribution and population structure can enhance the understanding of the dynamics shaping these attributes over time. Moreover, if the quota is granted based on a density miscalculation, e.g., overestimating abundance to obtain larger catches, the population might be over-exploited.

In an influential paper, Orensanz et al. (2004) warned geoduck commercial fisheries that the species might notbe sustainablein the short-term. Geoducks have exhibited long life-history dynamics, and presentlyonly short-term information is available. Furthermore, environmental factors might affect density estimations, as well as the species life cycle. In the Pacific Northwest (British Columbia, Canada, and Washington State, USA), Valero et al. (2004) explored correlations between $P$. generosa recruitment, large river discharges, and sea surface temperatures. Their results indicated river discharges were negatively and temperature positively correlated with recruitment, but $r$-values were scale-dependent. In the upper Gulf of California, Calderon-Aguilera et al. (2010a) reported the reproductive cycle of $P$. globosa was coupled with pulses of higher primary productivity. Observations suggested geoduck larvae recruitment was consistent with that predicted by Cushing's (1969) match/mismatch hypothesis, which states successful recruitment depends on the timing of food availability and larval production.

The objective of this study was to analyze spatial distribution, population structure and the effect of chlorophyll $a$ concentration, sea surface temperature, turbidity, and tidal cycle on density estimation of $P$. globosa in the central Gulf of California, using remote sensing and field survey data.

\section{MATERIALS AND METHODS}

\section{STUdy AREA AND SAMPLE COLleCtion}

The Gulf of California experiences seasonally reverse circulation: cyclonic in summer and anticyclonic in winter (Soria et al. 2014).
The anticyclonic period lasts from November to April. Flow is northward on the peninsular and southward on the mainland coasts. This configuration produces upwelling along the continental margin enriching the waters, which was identified by satellite imagery (Lluch-Cota et al. 1999). The main difference between inner waters of the Gulf of California and the adjacent open Pacific is the presence of a high-salinity near surface water mass in the Gulf, which results in modifications by mixing surface water from the eastern tropical Pacific (Hammann et al. 1998). The study area comprised a portion of the CGC $\left(27^{\circ} 56.6^{\prime} \mathrm{N}\right.$ $111^{\circ} 1.4^{\prime} \mathrm{W}$ to $27^{\circ} 5.4^{\prime} \mathrm{N}-110^{\circ} 14.6^{\prime} \mathrm{W}$; Fig. 1). Hammann et al. (1998) described a major gyre system in the central Gulf; this gyre provides an ideal combination of factors for retention of geoduck larvae. Mean surface temperature varies from $17.5^{\circ} \mathrm{C}$ in January to $32^{\circ} \mathrm{C}$ in August. The study area sediments are of 3 main types: (i) fine sand, located in the northern section of the study area; (ii) loamy sand, distributed in the central part of the study area; and (iii) silt-clay, confined to the southern study area (Sánchez et al. 2009). It was restricted the fishing area to the 30 $\mathrm{m}$ isobath to assure diver safety, and because it is the maximum legal fishing depth (DOF 2012). It was first established a grid of $1000 \times 500 \mathrm{~m}$ with outer coordinates at $27.9 \mathrm{~N}-111 \mathrm{~W}$ and 27.1 $\mathrm{N}-110.3 \mathrm{~W}$ from the shoreline with a $30 \mathrm{~m}$ depth. Dives were subsequently conducted, where each dive counted all geoducks in a transect perpendicular to the coast $2 \mathrm{~m}$ wide by $25 \mathrm{~m}$ long, which covered a $50 \mathrm{~m}^{2}$ area (Fig. 1). Sampling the grid area resulted in 1791 dives conducted from November 2009 to January 2011 (Fig. 1).

In each point of the grid, commercial hookah divers harvested individual clams using a stinger (a high-flow hydraulic tool employed to uncover buried clams). Water was pumped into bottom sediments causing liquefaction of the substrate to facilitate clam extraction. After extraction from the sediment, the clams were transported to the laboratory in coolers, and they were processed immediately upon arrival. The collected organisms were tagged and weighed while alive, and their bodies were subsequently removed from the shells. After drying, shell length (the straight-line distance between the anterior and posterior shell margins) was measured to the nearest $0.1 \mathrm{~mm}$ using calipers.

Density was defined through the systematic sampling approach, and subsequent density estimates, which were expressed as geoduck number per diving hour (Catch Per Unit Effort-CPUE) were obtained from commercial divers. CPUE results were used for further comparisons with environmental variability. Length and weight data were also acquired from commercial catch.

${ }^{2}<$ http://www.conapesca.gob.mx/wb> 


\section{WEIGHT-LENGTH RELATIONSHIP}

The weight-length function, $W=a L^{b}$, was fitted to the data, where $W$ is the total wet weight in $\mathrm{g} ; L$ is shell length in $\mathrm{mm} ; a$ is intercept (the initial growth coefficient or condition factor); and $b$ is the allometric coefficient. In addition, a $t$-test was used to determine if the $b$-value was significantly different from isometric growth ( $b=3$; Zar 1999).

\section{SPATIAL Distribution}

Geoduck spatial distribution in the study area was estimated using the following 3 grid methods: (i) inverse distance to a power; (ii) minimum curvature; and (iii) point Kriging. All approaches were included in Surfer ${ }^{3}$. Kriging was selected because it resulted in better fit and least variance. This technique employs statistical functions of 2 points that describe an increase or decrease in correlation between samples, which are separated to determine a heterogeneous grid value from known neighbors' values. We used default values for the variogram model and tested residual distributions.

\section{ENVIRONMENTAL VARIABILITY}

Variability in Chl- $a$ concentration was examined using monthly ocean color images from October 2010 to December 2011. The images were obtained from SeaWiFS sensors and were compounded monthly with a resolution of $1 \mathrm{~km}$ per pixel ${ }^{4}$. Sea surface temperatures (SSTs) were obtained from NOAA_OI_SST_V2 data (Reynolds et al. 2002) provided by NOAA/OAR/ESRL PSD ${ }^{5}$. It was developed density overlays covering the entire study area, which showed the 3 highest density patches, in addition to density levels of other sampling sites (Fig. 2). MODIS-Aqua Level 1A data were obtained from the NASA Goddard Space Flight Center processed to a Level 2 format using NASA's SeaWiFS Data Analysis System (SeaDAS version 5.1.6) software, following Lahet \& Stramski (2010). Turbidity was estimated from satellite imagery (MODIS-Terra, available from NASA Level 1 and Atmosphere Archive and Distribution System $)^{6}$ with a spatial resolution of 1000, 500, and $250 \mathrm{~m}$ for each sampling date. Geographic and atmospheric correction was performed using
Figure 2. Density distribution of the geoduck Panopea globosa (org. $\mathrm{m}^{-2}$ ) in the central Gulf of California obtained by the Kriging ordinary method. The 3 denser beds (cores) are depicted / Distribución y densidad de la almeja de sifón Panopea globosa (org $\cdot \mathrm{m}^{-2}$ ) en la parte central del Golfo de California, obtenida con el método de Kriging ordinario. Se resaltan los 3 bancos de alta densidad

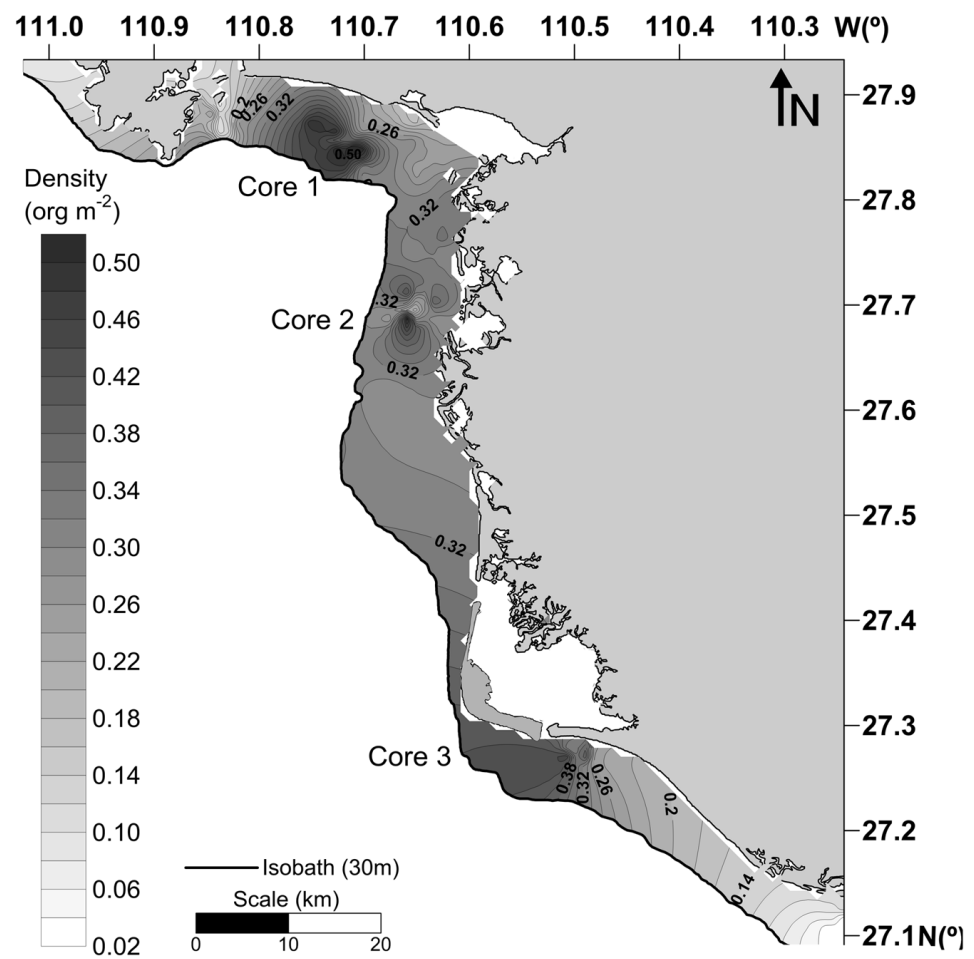

${ }^{5}<$ http://www.esrl.noaa.gov/psd>

${ }^{3}$ Golden Software, LLC. Surfer version $9<$ http://www. goldensoftware.com/products/surfer $>$

${ }^{4}<$ http://www.science.oregonstate.edu/ocean.productivity $>$
${ }^{6}<$ http://ladsweb.nascom.nasa.gov/data/search.html> 


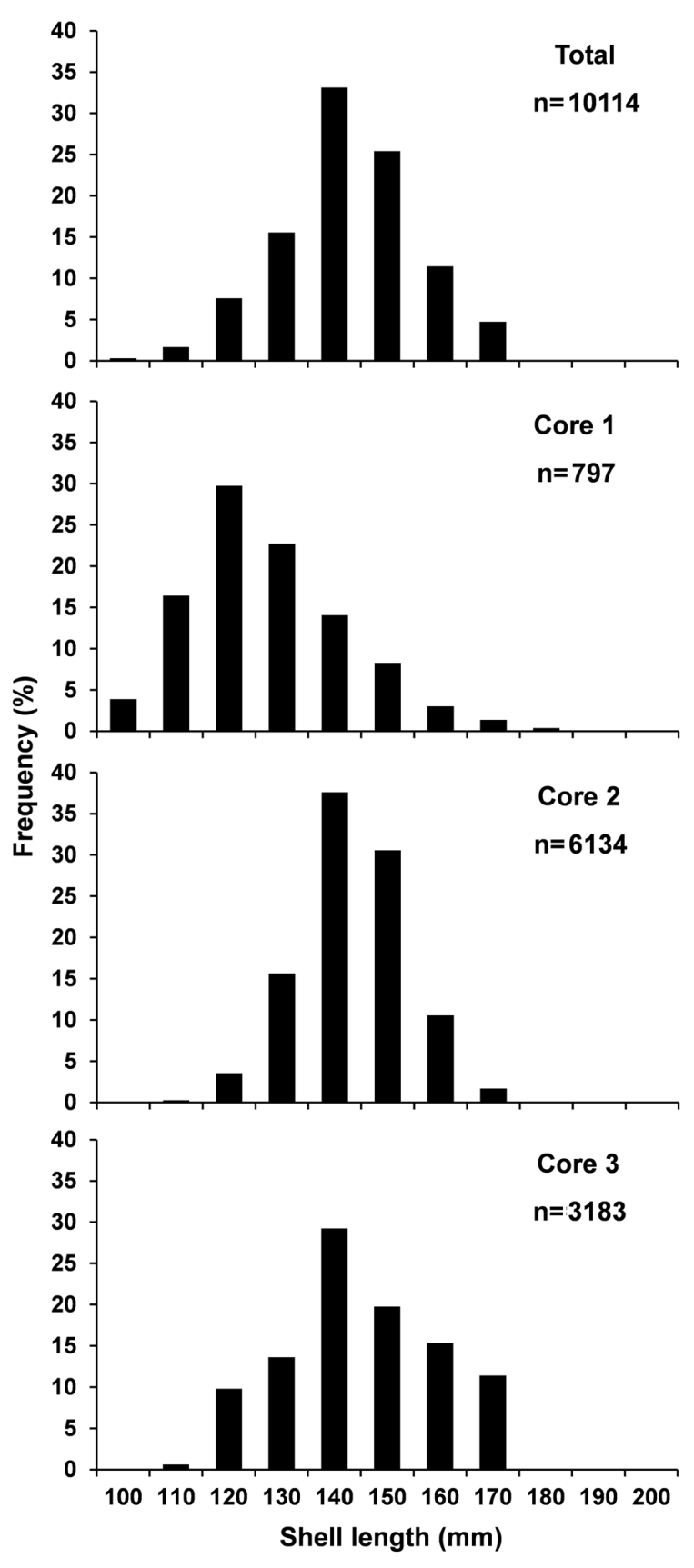

Figure 3. Length frequency distribution of Panopea globosa from the central Gulf of California at the $\mathbf{3}$ cores with the highest density / Frecuencias de longitud de la almeja de sifón Panopea globosa de la parte central del Golfo de California en los 3 bancos de alta densidad the algorithm developed by J. Descloitres, NASA Goddard Space Flight Center. Tides were measured using data available in the MAR V1.0 2011 program supported by CICESE7 ${ }^{7}$. This program applies in situ sea-level data from tidal gauges, and calculates tide height at a specific locality. It was selected a core zone 1, and followed fishing activities at three different times associated with different tide phases. A Pearson's correlation was used to measure the linear correlation (dependence) between an environmental variable and CPUE (i.e., proxy for geoduck density).

\section{RESULTS}

Kriging spatial interpolation output for the population distribution and density surveys are shown in Fig. 2. The figure depicts the interpolated geoduck density throughout the entire study zone. Three main core density areas (area in $\mathrm{km}^{2}$ ) were identified, with the highest density at each core approximately 0.5 geoducks $\mathrm{m}^{-2}$. Fine and loamy sands were predominant at cores $1\left(8 \mathrm{~km}^{2}\right)$ and $2\left(5 \mathrm{~km}^{2}\right)$, and silt-clay was the primary substrate at core $3\left(11 \mathrm{~km}^{2}\right)$. All 3 core areas were $\sim 20 \pm 5 \mathrm{~m}$ in depth.

A total of 10114 geoduck samples were analyzed from throughout the entire study zone and the study period. Geoduck shell length-frequency distribution ranged from 100 to $180 \mathrm{~mm}$ (Fig. 3), and the mode was $120 \mathrm{~mm}$ in core 1 and $140 \mathrm{~mm}$ in cores 2 and 3. Total weight ranged from 460 to $2000 \mathrm{~g}$ (Fig. 4), and the mode varied from $800 \mathrm{~g}$ in core 1 to $1000 \mathrm{~g}$ in cores 2 and 3. The weight-length relationship indicated negative allometric growth for each core (Fig. 5 ; $t$-test, $P<0.05$ ).

Chl- $a$ values recorded from October 2010 to January 2011 fluctuated in each of the 3 core areas. Values in cores 1 and 2 varied from 3 to $7 \mathrm{mg} \mathrm{m}^{-3}$, while in core 3 , they varied from 2 to $7 \mathrm{mg} \mathrm{m}^{-3}$ (Fig. 6a). The sea surface temperature (SST) showed a sharp decline from $28^{\circ} \mathrm{C}$ in October 2010 to $10^{\circ} \mathrm{C}$ in January 2011 in each of the 3 cores analyzed (Fig. 6b). Turbidity fluctuated from 40 to 160 units. The CGC showed a mixed semidiurnal tidal cycle; therefore, the zone presented 2 uneven tides per day, or one high and one low tide per day in some cases. The amplitude tidal range was only $600 \mathrm{~mm}$ to $-595 \mathrm{~mm}$ (Fig. 7).

Geoduck density obtained from commercial activities, using CPUE as an index of relative abundance, showed a positive relationship with Chl- $a$ and turbidity but a negative relationship with SST (Figs. 6a, b, and c). The other environmental variable examined was tidal phase. The results showed the lowest geoduck density was recorded when divers collected clams from a tidal height of $400 \mathrm{~mm}$ to $-200 \mathrm{~mm}$, and the highest one was obtained when divers performed collections above a $600 \mathrm{~mm}$ tidal height (Fig. 7).

${ }^{7}<$ http://oceanografia.cicese.mx/predmar> 


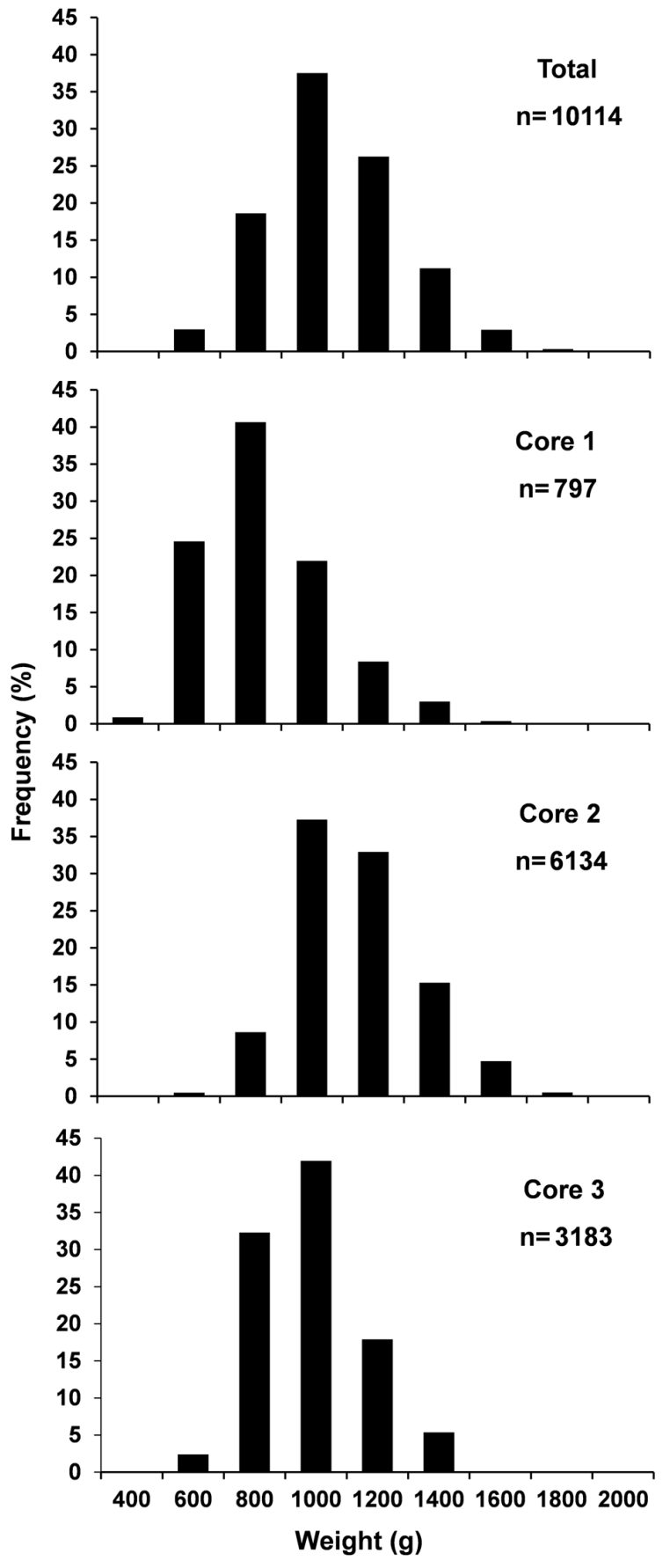

Figure 4. Weight frequency distribution of Panopea globosa from the central Gulf of California at the 3 cores with the highest density / Frecuencias de peso de la almeja de sifón Panopea globosa de la parte central del Golfo de California en los 3 bancos de alta densidad
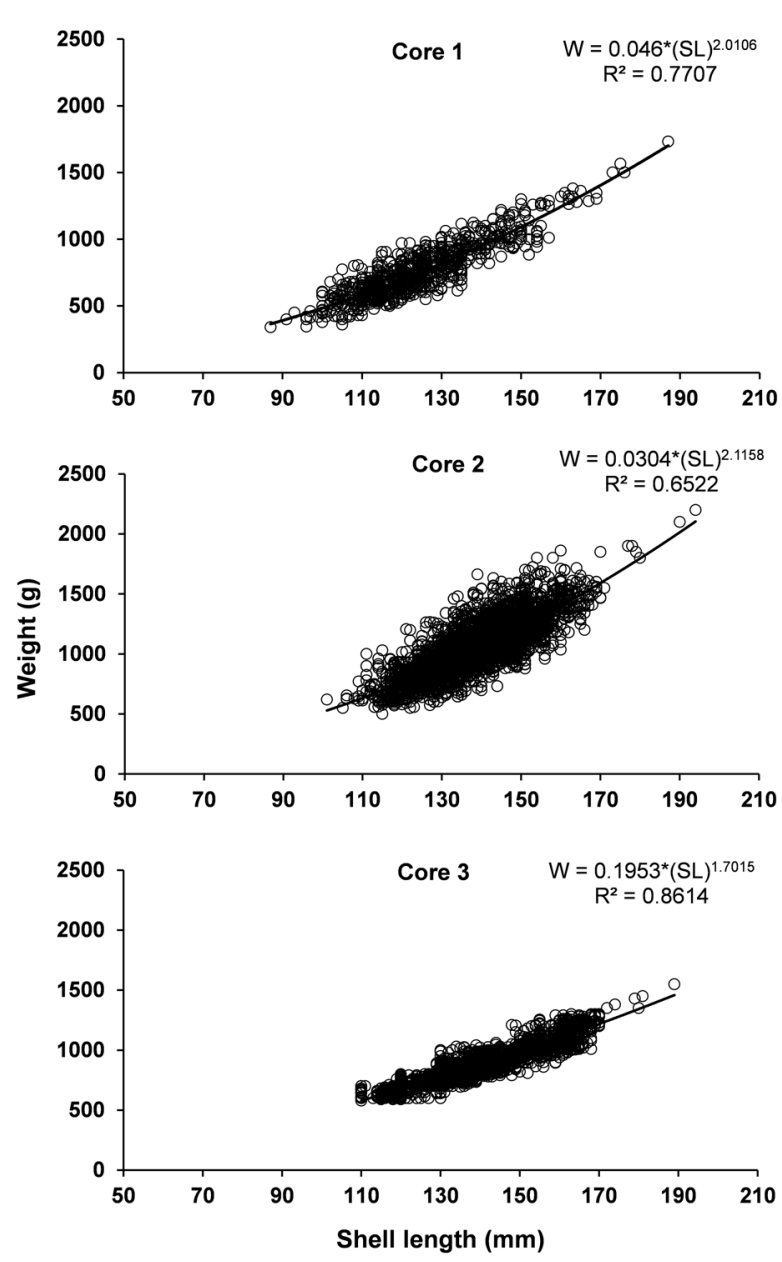

Figure 5. Shell length-total weight relationship for Panopea globosa from the central Gulf of California at the 3 cores with the highest density / Relación longitud-peso de la almeja de sifón Panopea globosa de la parte central del Golfo de California en los 3 bancos de alta densidad

\section{Discussion}

A unimodal size structure in P. globosa was documented in the central and upper Gulf of California. The first study (Aragón-Noriega et al. 2007) reported a mean shell length (SL) of $203 \mathrm{~mm}$. Subsequently, a $93 \mathrm{~mm}$ modal size and mean $109.8 \mathrm{~mm}$ SL were estimated (Cortez-Lucero et al. 2011, Cruz-Vásquez et al. 2012). Results from the upper Gulf of California showed average $P$. globosa SL varied between 140 and $150 \mathrm{~mm}$ on the west coast (Calderon-Aguilera et al. 2010b), and mean $160.3 \mathrm{~mm}$ on the east coast (PérezValencia \& Aragón-Noriega 2012). In our study, the unimodal length-distribution patterns were similar in each of the three core areas evaluated. This unimodal size structure suggested a poor recruitment pulse and lower mortality in the adult stage. 


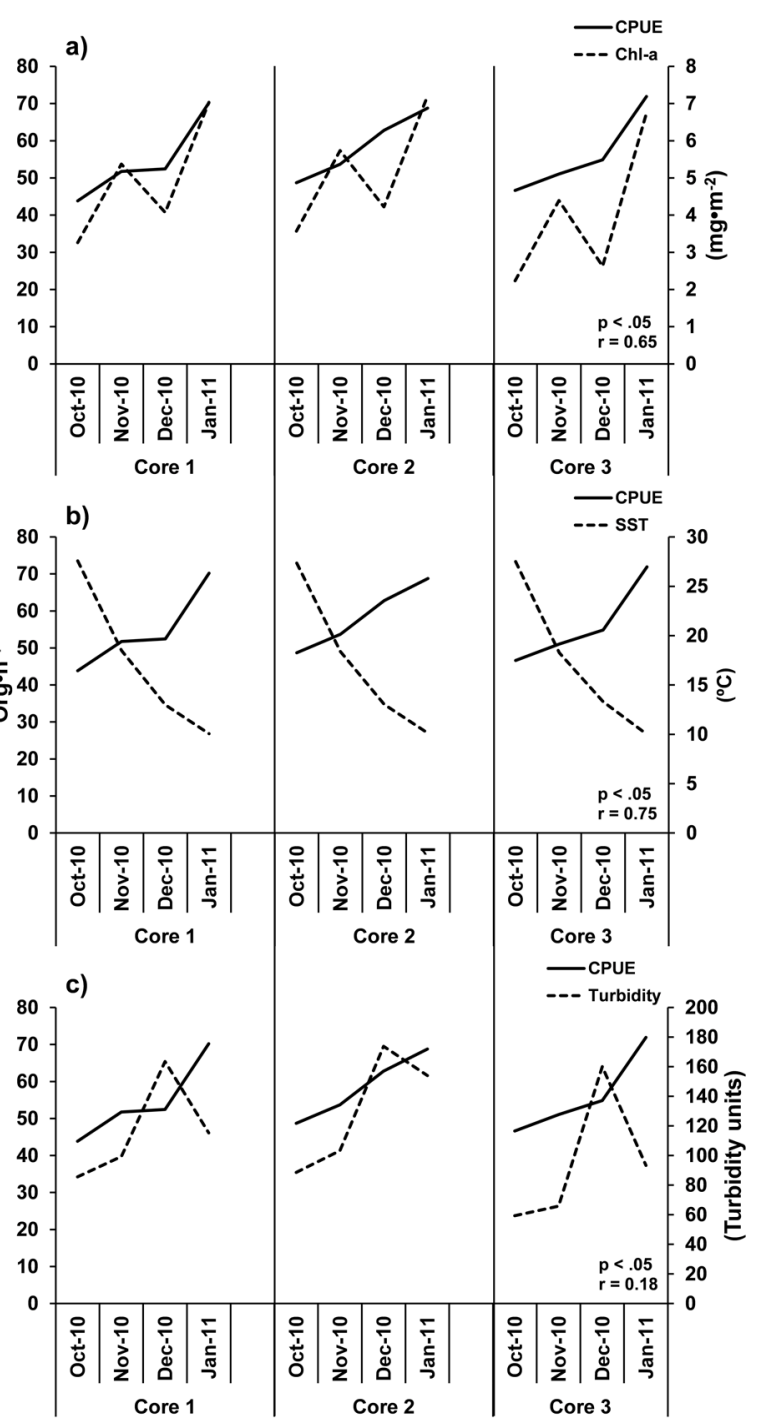

Figure 6. Temporal density variation and environmental parameters in each core; (a) Chl-a, (b) SST and (c) turbidity. The CPUE (org $\left.\cdot h^{-1}\right)$ is superimposed on each graph / Variación temporal de la densidad y variables ambientales en cada banco; a) Chl-a, b) TSM y c) turbidez. En cada gráfica se ha superpuesto la CPUE (org $\left.\cdot h^{-1}\right)$

The length-weight relationship and $b$-values detected in our study were congruent with results reported in other geoducks, i.e., Calderon-Aguilera et al. (2010b) for P. generosa in the northwestern Mexican Pacific and Andersen (1971) in Washington State coastal waters. The $b<3$ value determined in our study was consistent with geoduck shape. The $b<3$ value suggested large specimens depicted a more elongated body shape or small specimens were in better nutritional condition at the time of sampling.

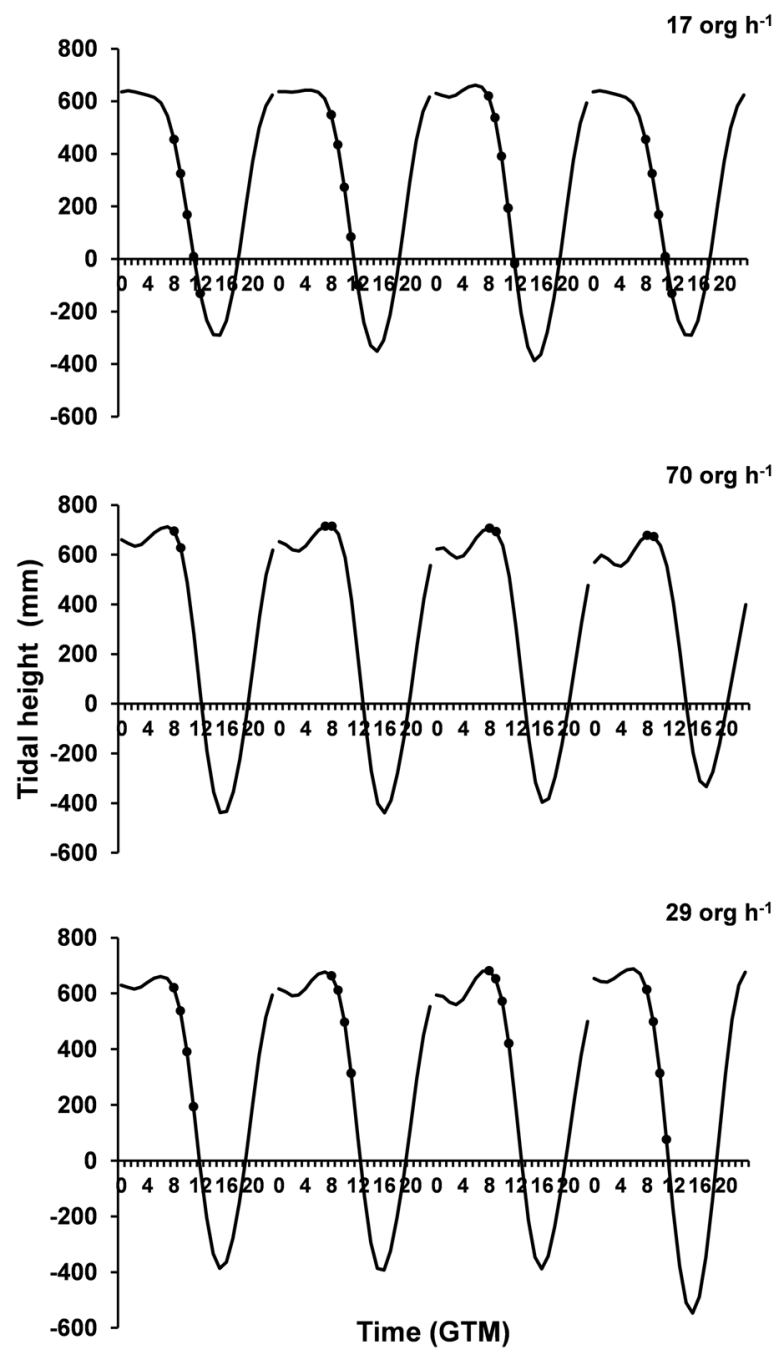

Figure 7. Relationship of Panopea globosa CPUE (org' $h^{-1}$ ) and tide height in the study area. CPUE data from commercial divers; Tide height from M AR V1.02011 program (available at: http:/ / oceanografia.cicese.mx/ predmar) / Relación de la CPUE (org $\cdot \mathrm{h}^{-1}$ ) de Panopea globosa con la altura de la marea en el área de estudio. La CPUE fue obtenida del buceo comercial; la altura de la marea del programa MAR V1.0 2011 (disponible en: http://oceanografia.cicese.mx/predmar)

In a previous study conducted in the area Cortez-Lucero $e t$ al. (2014) discussed on the possible effect of larval density and bed connectivity, food supply, substrate, and hydrographic conditions. They argue that larval dispersal is most influenced by hydrography because the pelagic phase is relatively long (up to 25 days); therefore, currents determine larval aggregations, which affect settlement and recruitment. Also, the pediveliger larvae of some bivalves, e.g., pectinids settle when they reach 180-200 $\mu \mathrm{m}$ long (Uriarte et al. 2002). However, if larvae drift 
and settle in non-suitable substrate, they will die. Becker et al. (2012) reported some low-swimming capacity larvae take advantage of currents, depending on depth. Therefore, larval stage duration is critical for successful settlement. The larval stage lasts from 16-47 days in P. generosa (Becker et al. 2012). However, larval dispersion behavior and distribution is unknown in P. globosa. Panopea generosa is considered the most studied geoduck species. Becker et al. (2012) indicated their study is one of the very few that focused on P. generosa larval behavior, and the results found no correlation between larval abundance and any physical variable.

In some areas with aggregated populations, Naidu \& Anderson (1984) described self-sustainable populations due to oceanographic features causing water circulation, resulting in a mechanism for larvae retention in the same area as the spawning stock populations. In the central Gulf of California (our study area), Hammann et al. (1998) characterized a major gyre system providing an ideal combination of factors for larvae retention. Geoducks are sessile species that live buried in the seafloor, and this characteristic could influence the larval settling process. It is possible pediveliger larvae transported by sea currents aggregate at the bottom, where they seek similar substrates for fixation and posterior metamorphosis. Thus, geoducks are recruited in patches, and individuals that remain close to adults are also close enough to each other to ensure reproduction.

In our study, we found significantly different densities among beds 1,2 , and $3(P<0.05)$. We did not collect sediment samples. However, Sánchez et al. (2009) characterized the following three main sediment types from the study area: (i) core 1 - fine sand, located in the northern section of the study area; (ii) core 2 loamy sand, distributed in the central part of the study area; and (iii) core 3 - silt-clay, confined to the southern study area. Goodwin \& Pease (1991) described the spatial distribution of $P$. generosa in 6 areas from Puget Sound, Washington. Their results showed significant differences in clam density among different sediments with 1.2 clams $\mathrm{m}^{-2}$ in silty, 2.0 clams $\mathrm{m}^{-2}$ in silt-sandy, and 2.1 clams $\mathrm{m}^{-2}$ in sandy sediments; they concluded $P$. generos $a$ exhibited increased density in sandy-silt and sand substrates.

Density assessment plays an important role in managing Geoduck fisheries in Mexico because its exploitation should be performed by beds. Mexican authorities have a mandatory management program in geoduck fishery that a bed is a regulated area with defined geographical limits whose density is suitable for fisheries. Thus, a method toestimate density was established. The method must be applied in all the areas, and it must be identical or similar. The density estimation method is an adaptation of the one developed in Washington for the geoduck clam (Brandbury et al. 2000). However, Brandbury et al. (2000) reported that density estimation could be biased by turbidity, oceanographic currents, or temperature. Our results suggest that the tide phase should be taken into account as a factor affecting geoduck observation. As density plays an important role not only in defining the bed area (or bed geographic limits) but also the quota assigned, it is necessary to focus on the environmental factors that could affect geoduck counts. The authorities in Mexican fisheries have emphasized on identifying density variability to allow the sustainable exploitation of geoduck in Mexican fishing areas. For these reasons, our studyis useful to determine the factors affecting density estimations.

Continuous improvements should be made in density estimations as the results of field surveys, as those of our study, to better define bed areas and capture quota. Density estimates should be modified according to those determined by the quotas if the intention is achieving a sustainable fishery.

Higher geoduck production might show increased density or individual mean weight; however, we found a strong positive correlation between geoduck density (expressed as CPUE) with Chl- $a$ and temperature and a weak positive correlation with turbidity. It must be emphasized that this analysis was rather simplistic because many other compounding factors, such as prerecruitment mortality, cohort strength, and age structure might be deterministic factors in the observed density and size distribution. Based on our observations and reviews of other studies, water depth and substrate type seem much better physical variables to correlate with distribution data even though we did not detect correlations.

One caveat of our study is we should have aged all specimens to cross-correlate primary productivity and recruitment. A lag between primary productivity and recruitment might be expected. Another caveat to our study is the absence of a show factor assessment as in Bradbury et al. (2000). Therefore, turbidity and tide effects on density estimates were confounding because we did not have comparative surveys. Moreover, divers themselves cause turbidity by sediment disturbance. Nevertheless, we are confident in the estimated geoduck densities due to the large number of dives (1791) and the robust grid method used for sampling.

In summary, $P$. globosa in the Central Gulf of California exhibits a patchy distribution with densities up to $0.5 \mathrm{ind} \cdot \mathrm{m}^{-2}$. However, this distribution was poorly correlated with Chl- $a$, sea temperature, turbidity, and tide cycles at the time of sampling. Moreover, we do not have enough information to rule out a timelagged relationship. Therefore, the next steps for this research must be to correlate water depth and substrate type with distribution data and ageing of organisms. 


\section{ACKNOWLEDGMENTS}

EAAN received financial support from CIBNOR (Project 9011). The Ricardo Loreto fishing cooperative kindly provided logistical and diving team support for this project. JEMM thanks CONACYT for a studentship (368575); professional editing by J. Schultz and D. Dorantes is also appreciated. Three anonymous reviewers improved substantially the former version of this manuscript.

\section{LITERATURE CITED}

Andersen AM. 1971. Spawning, growth, and spatial distribution of the geoduck clam, Panopea generosa Gould, in Hood Canal, Washington. Doctoral Thesis, University of Washington, Seattle, 133 pp.

Aragón-Noriega EA, E Alcántara-Razo, LE CalderonAguilera \& R Sánchez-Fourcade. 2012. Status of geoduck clam fisheries in Mexico. Journal of Shellfish Research 31: 733-738.

Aragón-Noriega EA, J Chávez-Villalba, PE Gribben, E Alcántara-Razo, A Maeda-Martínez, E Arambula-Pujol, A García-Juárez \& R Maldonado-Amparo. 2007. Morphometric relationships, gametogenic development and spawning of the geoduck clam Panopea globosa (Bivalvia: Hiatellidae) in the central Gulf of California. Journal of Shellfish Research 26: 423-431.

Arámbula-Pujol EM, AR García-Juárez, E Alcántara-Razo \& EA Aragón-Noriega. 2008. Aspectos de biología reproductiva de la almeja de sifón Panopea globosa (Dall 1898) en el Golfo de California. Hidrobiológica 18: 89-98.

Becker BJ, MD Behrens, YRA Shevalier, CM Henzler, EA Hoaglund \& BK Lemay. 2012. Determining distribution and size of larval Pacific geoduck clams (Panopea generosa Gould 1850) in Quartermaster Harbor (Washington, USA) using a novel sampling approach. Journal of Shellfish Research 31(3): 711-723.

Bradbury A, B Sizemore, D Rothaus \& M Ulrich. 2000. Stock assessment of subtidal geoduck clams (Panopea abrupta) in Washington. Marine Resources Unit, Fish Management Division, Fish Program, Washington Department of Fish and Wildlife, Washington, 80 pp. <http:/ /wdfw.wa.gov/publications/00224/wdfw00224.pdf>

Calderon-Aguilera LE, EA Aragón-Noriega, H ReyesBonilla, CG Paniagua-Chávez, AE Romo-Curiel \& VM Moreno-Rivera. 2010a. Reproduction of the Cortes geoduck Panopea globosa (Bivalvia: Hiatellidae) and its relationship with temperature and ocean productivity. Journal of Shellfish Research 29: 135-141.

Calderon-Aguilera LE, EA Aragón-Noriega, CM Hand \& VM Moreno-Rivera. 2010b. Morphometric relationships, age, growth, and mortality of the geoduck clam, Panopea generosa, along the Pacific coast of Baja California, Mexico. Journal of Shellfish Research 29: 319-326.
CONAPESCA. 2012. Anuario estadístico de pesca. Mazatlán. Secretaría de Agricultura, Ganadería, Desarrollo Rural, Pesca y Alimentación-Comisión Nacional de Acuacultura y Pesca. Mazatlán, México. <http://www.conapesca.sagarpa.gob.mx/ wb/cona/anuario_2012_zip>

Cortez-Lucero G, JA Arreola-Lizárraga, J Chávez-Villalba \& EA Aragón-Noriega. 2011. Edad, crecimiento y mortalidad de la almeja de sifón, Panopea globosa (Bivalvia: Hiatellidae) en la región central del Golfo de California, México. Revista de Biología Marina y Oceanografía 46: 453-462.

Cortez-Lucero G, JA Arreola-Lizárraga, J Chávez-Villalba \& EA Aragón-Noriega. 2014. Distribución y abundancia de la almeja de sifón Panopea globosa (Bivalvia: Hiatellidae), en la región central del Golfo de California, México. Hidrobiológica 24: 167-174.

Cruz-Vásquez R, G Rodríguez-Domínguez, E Alcántara-Razo \& EA Aragón-Noriega. 2012. Estimation of individual growth parameters of the Cortes geoduck Panopea globosa from the central gulf of California using a multimodel approach. Journal of Shellfish Research 31: 725-732.

Cushing DH. 1969. The regularity of the spawning season of some fishes. Journal du Conseil Permanent International pour I’Exploration de la Mer 33: 81-92.

Goodwin CL \& BC Pease. 1991. Geoduck, Panopea abrupta (Conrad, 1849), size, density, and quality as related to various environmental parameters in Puget Sound, Washington. Journal of Shellfish Research 10: 65-77.

Hammann MG, MO Nevarez-Martínez \& Y Green-Ruiz. 1998. Spawning habitat of the Pacific sardine (Sardinops sagax) in the Gulf of California: egg and larval distribution 1956-1957 and 1971-1991. California Cooperative Oceanic Fisheries Investigations Reports 39: 169-179.

Hendrickx ME, RC Brusca \& LT Findley. 2005. A distributional checklist of the macrofauna of the Gulf of California, Mexico. Part. 1 Invertebrates, 429 pp. ArizonaSonora Desert Museum, Arizona.

Keen AM. 1971. Sea shells of tropical west America. Marine mollusks from Baja California to Peru, 1064 pp. Stanford University Press, California.

Lahet F \& D Stramski. 2010. MODIS imagery of turbid plumes in San Diego coastal waters during rainstorm events. Remote Sensing of Environment 114: 332-344.

Leyva-Valencia I, ST Álvarez-Castañeda, DB Lluch-Cota, S González-Pelez, S Pérez-Valencia, B Vadopalas, S Ramírez-Pérez \& P Cruz-Hernández. 2012. Shell shape differences between two Panopea species and phenotypic variation among $P$. globosa at different sites using two geometric morphometrics approaches. Malacologia 55: 1-13.

Lluch-Cota SE, DB Lluch-Cota, D Lluch-Belda, MO Nevárez-Martínez, A Parés-Sierra \& S HernándezVázquez. 1999. Variability of sardine catch as related to enrichment, concentration, and retention processes in the Central Gulf of California. California Cooperative Oceanic Fisheries Investigations Reports 40: 184-190. 
Naidu K \& J Anderson. 1984. Aspects of scallop recruitment on Saint Pierre bank in relation to oceanography and implications for resource management. Canadian Atlantic Fisheries Science Advisory Committee Research Document 84/29: 1-15.

Orensanz JM, CM Hand, AM Parma, J Valero \& $R$ Hilborn. 2004. Precaution in the harvest of Methuselah's clams; the difficulty of getting timely feedback from slowpaced dynamics. Canadian Journal of Fisheries and Aquatic Science 61: 1355-1372.

Pérez-Valencia SA \& EA Aragón-Noriega. 2012. Determinación de biomasa y bancos de la almeja de sifón Panopea globosa (Dall, 1898) en una zona virgen del alto golfo de California. Interciencia 37: 651-656.

Reynolds RW, NA Rayner, TM Smith, DC Stokes \& W Wang. 2002. An improved in situ and satellite SST analysis for climate. Journal of Climate 15: 1609-1625.

Sánchez A, S Aguíñiga, D Lluch-Belda, J CamalichCarpizo, PD Monte-Luna, G Ponce-Díaz \& F ArreguínSánchez. 2009. Geoquímica sedimentaria en áreas de pesca de arrastre y no arrastre de fondo en la costa de SinaloaSonora, Golfo de California. Boletín de la Sociedad Geológica Mexicana 61:25-30.

Soria G, J Torre-Cosio, A Munguia-Vega, S GuidoMarinone, MF Lavín, A Cintri \& M Moreno-Báez. 2014. Dynamic connectivity patterns from an insular marine protected area in the Gulf of California. Journal of Marine System 129: 248-258.
Suárez-Moo PD, LE Calderon-Aguilera, H Reyes Bonilla, G Díaz-Erales, V Castañeda-Fernández-de-Lara, EA Aragón-Noriega \& A Rocha-Olivares. 2013. Integrating genetic, phenotypic and ecological analyses to assess the variation and clarify the distribution of the Cortes geoduck (Panopea globosa). Journal of the Marine Biological Association of the United Kingdom 93: 809-816.

Uriarte I, G Rupp \& A Abarca. 2002. Producción de juveniles de pectínidos iberoamericanos bajo condiciones controladas. En: Maeda-Martínez AN (ed). Los moluscos pectínidos de Iberoamérica: Ciencia y acuicultura, pp. 147-172. Limusa, La Paz.

Valero JL, C Hand, J Orensanz, AM Parma, D Armstrong \& R Hilborn. 2004. Geoduck (Panopea abrupta) recruitment in the Pacific Northwest: Long-term changes in relation to climate. California Cooperative Oceanic Fisheries Investigations Reports 45: 80-86.

Zar JH. 1999. Biostatistical analysis, 663 pp. Prentice-Hall, Upper Saddle River. 